\title{
PENGARUH KUALITAS PRODUK DAN CITRA MEREK TERHADAP KEPUTUSAN PEMBELIAN KONSUMEN NATURE REPUBLIC DI SURABAYA
}

\author{
Annisa Ristanti \\ Universitas Negeri Surabaya \\ annisaristanti16080574017@mhs.unesa.ac.id \\ Sri Setyo Iriani \\ Universitas Negeri Surabaya \\ srisetyo@unesa.ac.id
}

\begin{abstract}
Korean wave's existence makes Indonesian people interested in Korean cosmetics. One of the most favored Korean cosmetic brands in Indonesia is the Nature Republic, they have problems regarding the counterfeiting and illegal smuggling of some of their products. The purpose of this research is to analyze and discuss the influence of product quality and brand image on Nature Republic consumer purchasing decisions in the city of Surabaya. This research is a conclusive study with quantitative data analysis. Using a non-probability sampling technique with judgmental sampling. The number of samples in this study amounted to 110 respondents. The technique of collecting data using questionnaires that are used a Likert scale as the measurement and using multiple linear regression analysis techniques with application computer program SPSS 25 for Windows. The results of multiple linear regression analysis showed that product quality has a significant influence on purchasing decisions with a significant value of 0.003. As well as the brand image variable which has a significant value of 0,000, so that the brand image variable is known to have a significant influence on purchasing decisions. The indicator with the highest value of product quality is the impression of quality, then the brand image is the product image. Based on the results and discussion of the research, the managerial implications that can be applied are maintaining and improving product quality and brand image to increase consumer demand, have a competitive advantage, and benefit the company in terms of market expansion.
\end{abstract}

Keywords: brand image; product quality; purchase decision.

\section{PENDAHULUAN}

Kemenperin mencatat pertumbuhan kosmetik di Indonesia mencapai 7\% pada tahun 2019 (Huda, 2020). Tetapi produk kosmetik impor masih membanjiri pasar Indonesia dan nilai impornya naik setiap tahun (Taqwa, 2020). Menurut Taqwa (2020) negara yang terkenal sebagai produsen kosmetik berasal dari kawasan Eropa, Amerika, dan Jepang telah lama mengembangkan dan memasarkan produknya di Indonesia. Dengan mengambil pasar premium sebagai target, karena produknya terkenal mewah serta memiliki harga yang cukup tinggi. Persaingan antara kosmetik asing dan kosmetik Indonesia sangat sengit, menurut data survei yang dilakukan oleh Nielsen (2016) preferensi kosmetik konsumen Indonesia 48\% lebih memilih menggunakan kosmetik global, 36\% memilih kosmetik lokal, dan $16 \%$ lainnya tidak memilih prefrensi kosmetik apapun.

Sekarang ini sejumlah masyarakat mulai bergeser dari brand kosmetik global ke kosmetik Korea (Lukihardianti \& Murdaningsih, 2018). Hal ini dikarenakan demam korean wave atau budaya Korea sedang melanda berbagai belahan dunia, tak terkecuali Indonesia (Bella, 2018). Penggemar korean wave tidak hanya sekedar mengidolakan $k$-pop atau artis $k$-drama, tetapi juga terpukau akan kecantikan yang dimiliki sang idola dan ingin mengikuti tampilan mereka. Sehingga membuat tren kecantikan Korea yang disebut dengan k-beauty juga banyak diminati (Pratama, 2018).

Survei dari Zap Beauty Index tahun 2020 negara asal brand skincare yang menjadi favorit wanita Indonesia yang pertama adalah Korea $(57,6 \%)$, yang kedua adalah Indonesia $(37,4 \%)$ dan yang ketiga Jepang $(22,7 \%)$ (ZAP, 2020). Salah satu alasan k-beauty digemari lantaran memperlihatkan kulit cerah bersinar namun tetap natural (Putri, 2019). 
Perkembangan $k$-beauty di Indonesia pada saat ini terdapat 5 merek kosmetik Korea yang diminati selama tahun 2019-2020, dilihat melalui google trends (2020). Nilai rata-rata popularitas Innisfree menjadi yang tertinggi (67) menjadikan Innisfree merek kosmetik Korea paling diminati, disusul dengan Nature Republic yang berada di peringkat 2 (63), kemudian Laneige (55), Some By Mi (39), dan Nacific (23). Tetapi menurut hasil pra penelitian dengan melibatkan 76 responden didapatkan hasil 54,5\% responden lebih memilih Nature Republic dibandingkan kosmetik korea lainnya.

Menurut perwakilan PT. NRI Global Mandiri yang merupakan distributor resmi Nature Republic di Indonesia dalam Hardum (2019), muncul sejumlah pelaku yang memanfaatkan brand Nature Republic dengan melakukan pemalsuan dan penyelendupan secara masif di Indonesia. Sarana yang digunakan untuk memasarkan produk Nature Republic palsu dengan menggunakan media sosial instagram, online shop, bahkan membuka toko untuk menjual Nature Republic palsu dan ilegal. Hal tersebut telah merugikan masyarakat dan telah menipu para konsumen.

Selain itu dari hasil pra penelitian yang dilakukan, diketahui $78 \%$ responden mengatakan bahwa mereka melihat dan medengar tentang isu pemalsuan dan produk ilegal Nature Republic dari teman, beauty vlogger, media sosial, internet, dan berita di TV. Produk Nature Republic yang banyak dipalsu adalah soothing \& moisture aloe vera $92 \%$ soothing gel. Menurut instagram resmi Nature Republic Indonesia (2018), untuk membedakan produk asli dan palsu dengan cara membeli secara langsung di official offline \& online store Nature Republic, produk resmi memiki tulisan hologram pada stiker produksi, kemudian dapat dengan melihat kode produksi, tulisan embos, dan detail logo kemasan.

Salah satu pertimbangan konsumen dalam memilih produk kosmetik adalah harganya yang terjangkau (Habibah \& Sumiati, 2016). Puspitasari et al. (2011) mengatakan jika kosmetik palsu cenderung menggunakan bahan berbahaya, dijual dengan harga yang jauh lebih murah daripada kosmetik aslinya. Oleh karena itu, observasi dilakukan dalam penelitian ini untuk membandingkan harga produk Nature Republic berdasarkan tempat pembelian.

Di Surabaya, Nature Republic memiliki 2 official store yaitu di tunjungan plaza 6 dan pakuwon mall yang menjual sekitar 287 produk berupa pack \& masker, poin make up, skin care, cleansing, dan mask sheet dengan kisaran harga Rp18.000-Rp1.362.000 (Naturerepublic.id, 2019). Sedangkan untuk Nature Republic yang dijual di tempat lain terdapat di kodam (2 penjual), DTC, rumah kosmetik carissa, dan royal plaza (4 penjual). Produk yang dijual terbatas hanya 2 produk yaitu nature republic soothing \& moisture aloe vera 92\% soothing gel dan nature republic sheet mask dengan harga Rp14.000-Rp98.000. sehingga dapat diartikan bahwa produk Nature Republic yang paling banyak dijual selain official store adalah nature republic soothing \& moisture aloe vera $92 \%$ soothing gel. Dengan harga jauh lebih murah dibandingkan dengan harga resmi di official store Nature Republic.

Salah salah satu cara untuk menetapkan harga adalah dengan melihat kualitas produknya. Hal tersebut sesuai yang di katakan Junianti (2003) bahwa kualitas merupakan keunggulan mutu produk disesuaikan berdasarkan harga yang sepadan. Menurut Kotler dan Keller (2009) untuk produk tertentu, konsumen tidak keberatan apabila harus membeli dengan harga relatif mahal asalkan kualitas produknya baik.

Kualitas produk, harga, dan promosi produk merupakan hal yang dipertimbangkan konsumen sebelum membeli. Kualitas produk mencerminkan tentang bagaimana produk tersebut dapat melakukan fungsinya sesuai dengan harapan konsumen (Erdalina \& Evanita, 2015). Brata et al. (2017) berpendapat bahwa kualitas produk adalah faktor untuk mendukung keputusan pembelian. Persaingan dan meningkatnya permintaan konsumen membuat perusahaan berusaha untuk menghasilkan produk berkualitas yang dapat bersaing di pasar.

Saputra et al. (2017) mengatakan bahwa kualitas produk memiliki peran penting terhadap keputusan pembelian yang dilakukan konsumen, sebab kualitas produk yang baik membawa dampak yang baik untuk perusahaan. Sejalan dengan penelitian yang dilakukan oleh Ananingsih et al. (2018); serta 
Annisa Ristanti \& Sri Setyo Iriani. Pengaruh Kualitas Produk dan Citra Merek terhadap Keputusan Pembelian Konsumen Nature Republic di Surabaya

Rahman \& Sitio (2019) membuktikan bahwa kualitas produk berpengaruh signifikan terhadap keputusan pembelian. Sedangkan menurut Pardede \& Haryadi (2017), keputusan pembelian konsumen tidak dipengaruh secara positif dan signifikan oleh kualitas produk.

Konsumen dalam melakukan pilihan untuk sebuah produk akan mempertimbangkan tentang merek mana yang akan dibeli (Sumarwan, 2015). Menurut American Marketing Association (AMA) dalam Kotler dan Keller (2009:5) merek merupakan nama, istilah, tanda untuk membedakan produk dengan pesaing. Siddiq (2013) mengatakan merek juga memberi manfaat bagi konsumen, di antaranya mengidentifikasi apa yang ditawarkan serta bagaimana kualitasnya.

Sebuah merek membutuhkan citra untuk mengkomunikasikan tentang nilai-nilai yang dimiliki kepada target pasar sasarannya. Citra merek adalah representasi dari keseluruhan persepsi terhadap merek yang terbentuk dari informasi dan pengalaman masa lalu. Preferensi dan keyakinan pada suatu merek berhubungan erat dengan citra terhadap merek tersebut (Setiadi, 2003). Konsumen merasa puas membeli produk dari merek-merek terkenal, karena konsumen memiliki keyakinan bahwa merek terkenal lebih bisa dipercaya (Lin, 2007).

Semakin terkenal merek maka akan semakin besar tanggung jawab perusahaan untuk menjaga citra agar tidak tercoreng dengan adanya masalah seperti isu atau berita negatif (Lengkong et al., 2017). Menurut Thurau et al. (2004) dalam (Anggitasari_,-2016) pada indikator E-WOM ada yang dinamakan dengan venting negative feelings merupakan keinginan mengungkapkan ketidakpuasan konsumen terhadap produk atau perusahaan. Upaya ini dilakukan dalam bentuk E-WOM negatif. Konsumen yang menggunakan $E$-WOM sebagai alat untuk menyampaikan pernyataan atau opini yang dimiliki tentang merek Nature Republic, dengan memberikan informasi E-WOM negatif apabila konsumen tidak puas akan merek Nature Republic. Hal ini berdampak buruk pada citra yang dimiliki oleh Nature Republic.

Citra merek yang positif dapat memberikan keuntungan bagi perusahaan di antaranya dapat menciptakan keunggulan bersaing (Yulianingsih, 2018). Citra merek digunakan perusahaan untuk membentuk cara yang tepat dalam merilis produk baru, jenis produk yang akan dibuat, jenis iklan yang akan dilakukan, dan jenis pelanggan yang menjadi target (Su \& Lai, 2017).

Produk yang mempunyai citra merek yang baik cenderung lebih mudah diterima konsumen (Andrianto \& Idris, 2013). Seperti yang dikatakan Setiadi (2003) bahwa kemungkinan konsumen dalam membeli didasarkan dari citra positif yang dimiliki oleh sebuah merek. Kemudian Lin (2007) mengatakan bahwa melalui citra merek, konsumen dapat mengetahui suatu produk, menilai kualitasnya, menurunkan risiko pada saat pembelian, dan memperoleh pengalaman serta kepuasan tertentu dari perbedaan beragam merek.

Rommy et al. (2018); Fianto et al. (2014); dan Mutiara \& Madiawati (2019) berpendapat bahwa citra merek memiliki dampak positif dan signifikan terhadap keputusan pembelian. Apabila semakin tinggi citra merek yang ada di benak konsumen maka semakin tinggi keputusan pembelian. Sedangkan hasil penelitian Sone (2019); dan Putri et al. (2018) diketahui bahwa variabel citra merek tidak berpengaruh secara signifikan terhadap keputusan pembelian.

Tujuan penelitian ini adalah untuk menguji serta menganalisis peran kualitas produk dan citra citra merek sebagai faktor penting yang mempengaruhi keputusan pembelian konsumen Nature Republic di Surabaya.

\section{KAJIAN PUSTAKA DAN PENGEMBANGAN HIPOTESIS}

\section{Perilaku Konsumen}

Perilaku konsumen merupakan keterlibatan secara langsung dalam mendapatkan, mengkonsumsi, dan menghabiskan produk dan jasa, termasuk proses keputusan yang mendahului dan mengikuti tindakan ini (Engel et al., 1995). Kemudian Sumarwan (2015:5) menjelaskan bahwa perilaku konsumen adalah 
semua kegiatan, tindakan, serta proses psikologis yang menjadi mendorong pada saat sebelum membeli, ketika membeli, menggunakan, menghabiskan produk dan jasa serta pada saat kegiatan mengevaluasi.

\section{Keputusan Pembelian}

Kotler \& Amstrong (2014) mendefinisikan keputusan pembelian adalah tahap proses keputusan dimana konsumen secara aktual melakukan pembelian produk. Penjelasan dari Swastha (2008:105112) keputusan pembelian yaitu pemahaman konsumen tentang keinginan dan kebutuhan akan suatu produk dengan menilai dari sumber-sumber yang ada dengan menetapkan tujuan pembelian serta mengidentifikasi alternatif, sehingga mengambil keputusan untuk membeli yang disertai dengan perilaku setelah melakukan pembelian. Mendukung pendapat dari Indrawati (2015) bahwa setiap konsumen melakukan berbagai macam keputusan tentang pencarian, pembelian, penggunaan beragam produk dan merek pada setiap priode tertentu. Maka dapat dijelaskan jika keputusan pembelian merupakan proses yang harus dilalui konsumen mulai dari menetapkan tujuan pembelian, mencari alternatif, hingga sampai melakukan pembelian.

Proses keputusan pembelian dipengaruhi oleh tiga faktor utama : (1) strategi pemasaran: dimulai dari mengidentifikasi kebutuhan konsumen kemudian memproduksi, meyakinkan konsumen untuk membeli hingga terjadi transaksi. Berguna untuk analisis lingkungan, riset pasar, segmentasi, positioning dan diferensiasi, serta bauran pemasaran (Sumarwan, 2015:17), (2) perbedaan individu, (3) faktor lingkungan (Sumarwan, 2015:10).

Indikator keputusan pembelian yang digunakan mengintegrasi dari penelitian Mutiara \& Madiawati (2019); dan Indrawati (2015), yaitu-: (1) pilihan penyalur: memilih tempat penjual untuk membeli produk yang dibutuhkan, (2) pilihan produk: menentukan tentang produk yang dibutuhkan, (3) waktu pembelian: menetapkan kapan waktu yang tepat untuk membeli produk, dan (4) frekuensi pembelian: seberapa sering dalam membeli produk.

\section{Kualitas Produk}

Menurut Kotler dan Keller (2009:143), kualitas produk adalah keseluruhan karakteristik produk atau jasa bergantung pada kemampuan untuk memenuhi kebutuhan konsumen baik yang tersurat maupun yang tidak. Kemudian menurut Ariyoto (2001:92) dalam (Saputra et al., 2017) kualitas adalah totalitas bentuk dan karakteristik barang yang menunjukkan kemampuannya untuk memuaskan kebutuhan dan keinginan dari konsumen. Tingkat kualitas produk ditentukan oleh tingkat kepuasan konsumennya setelah atau saat mengonsumsi produk tersebut (Rahman \& Sitio, 2019). Sama hal nya dengan pendapat Alfred (2013) kualitas adalah bagaimana penerima produk atau layanan memandang produk atau layanan sebelum membeli, setelah pengiriman, dan penggunaan. Dengan kata lain, kualitas adalah cara memuaskan konsumen. Sehingga dapat dijabarkan bahwa kualitas produk adalah segala ciri atau karakteristik yang dimiliki oleh sebuah produk untuk dapat memuaskan konsumen dengan cara memenuhi kebutuhan dan keinginannya.

Penelitian ini mengacu indikator kualitas produk dari Alfred (2013) dan Rahman \& Sitio (2019), yaitu : (1) kinerja: fungsi utama dari sebuah produk; (2) daya tahan: menunjukan usia produk atau seberapa lama produk dapat digunakan; (3) kesesuaian: karakteristik produk memenuhi standar; (4) keistimewaan: ciri tambahan yang dapat memberi manfaat lebih untuk kinerja produk; (5) keandalan: kemungkinan produk mengalami kegagalan atau kerusakan saat menjalankan kinerjanya; (6) estetika: daya tarik tampilan produk; (7) kesan dari kualitas: persepsi atau penilaian konsumen mengenai produk.

Ketika seorang konsumen berniat melakukan pembelian suatu produk, konsumen tersebut akan memilih produk yang dari segi kualitas akan memenuhi kebutuhan mereka/ menyelesaikan masalah mereka (Rahman \& Sitio, 2019). Brata et al. (2017) dalam menjelaskan bahwa kualitas produk adalah faktor untuk mendukung keputusan pembelian. Sama dengan yang dikatakan Saputra et al. (2017) kualitas produk memiliki peran penting terhadap keputusan pembelian yang dilakukan konsumen. Hal 
Annisa Ristanti \& Sri Setyo Iriani. Pengaruh Kualitas Produk dan Citra Merek terhadap Keputusan Pembelian Konsumen Nature Republic di Surabaya

tersebut sejalan dengan penelitian Erdalina \& Evanita (2015); Alfred (2013); dan Ananingsih et al. (2018), kualitas produk berpengaruh signifikan terhadap keputusan pembelian. Tetapi penelitian ini tidak sejalan dengan penelitian yang dilakukan oleh Pardede \& Haryadi (2017) bahwa keputusan pembelian konsumen tidak dipengaruh secara positif dan signifikan oleh kualitas produk.

H1: Diduga ada pengaruh antara kualitas produk terhadap keputusan pembelian konsumen Nature Republic di Surabaya

\section{Citra Merek}

Supriyadi et al. (2016) mengartikan citra merek sebagai suatu pencitraan sebuah produk dibenak konsumen secara massal. Setiap orang akan memiliki pencitraan yang sama terhadap sebuah merek. Citra merek adalah mempresentasikan asosiasi-asosiasi yang diaktifkan dalam memori ketika berfikir mengenai merek tertentu (Shimp, 2014:40). Menurut Kotler dan Keller (2009:403) citra merek adalah presepsi dan keyakinan konsumen sebagai refleksi dari asosiasi yang muncul dibenak konsumen ketika mengingat suatu merek. Maka dapat dipaparkan bahwa citra merek adalah kesan yang dimiliki oleh konsumen tentang sebuah merek yang tertanam dalam memori atau ingatan. Citra merek dan produk yang baik akan mendorong calon pembeli untuk membeli produk ke merek tertentu serta tidak mempertimbangkan merek lain (Rommy et al., 2018). Kesan yang baik terhadap sebuah merek akan muncul jika merek memiliki keunggulan, keunikan, populer, dapat dipercaya (Fianto et al., 2014)

Terdapat 2 manfaat citra merek. Citra yang lebih positif terhadap sebuah merek memungkinkan konsumen untuk melakukan pembelian. Selain itu, memanfaatkan citra merek positif yang dimiliki merek produk lama, dapat membantu perusahaan untuk melakukan strategi merek (perluasan lini, perluasan merek, merek baru) dengan mudah karena konsumen suah mengenal produk yang lama (Sutisna, 2001).

Indikator citra merek yang digunakan merujuk pada Supriyadi et al. (2016); dan Li et al. (2011), yaitu: (1) citra produk: kesan yang ada pada ingatan konsumen tentang sebuah produk. (2) citra pemakai: kesan tampilan yang akan didapat konsumen setelah menggunakan suatu produk.

Menurut Rommy et al. (2018), konsumen yang memiliki citra positif suatu merek akan lebih cenderung melakukan pembelian. Supriyadi et al. (2016) berpendapat bahwa citra yang terbentuk dari asosiasi yang mendasari dari keputusan pembelian konsumen. Didukung penelitian sebelumnya dari Mutiara \& Madiawati (2019); Rommy et al. (2018); dan Fianto et al. (2014) bahwa citra merek memiliki dampak positif dan signifikan terhadap keputusan pembelian. Sedangkan Sone (2019); dan Putri et al. (2018) menyatakan tidak ada pengaruh secara signifikan citra merek terhadap keputusan pembelian.

H2: Diduga ada pengaruh antara citra merek terhadap keputusan pembelian konsumen Nature Republic di Surabaya

\section{METODE PENELITIAN}

Penelitian ini menggunakan jenis penelitian konklusif untuk menguji sebuah hipotesis atau mencari hubungan antar variabel. Analisis data yang digunakan adalah kuantitatif. Populasi dalam penelitian ini adalah konsumen Nature Republic diSurabaya yang berjumlah infinite yang memiliki kararkteristik pernah membeli dan menggunakan produk Nature Republic minimal satu kali dalam setahun terakhir, membeli produk di official store Nature Republic yang berada di Surabaya (Tunjungan Plaza dan Pakuwon Mall), mengetahui isu tentang pemalsuan dan produk ilegal Nature Republic, memiliki usia 15-60 tahun, sesuai dengan segmentasi pasar dari Nature Republic. Sampel pada penelitian ini adalah 100 responden kemudian untuk mecegah kesalahan atau kerusakan data responden maka ditambahkan 10\% dari jumlah responden sehingga sampel berjumlah 110 responden. Menggunakan teknik pengambilan sampel non probability sampling, dengan metode judgemental. 
Penelitian ini menggunakan variabel kualitas produk dan citra merek sebagai variabel bebas, serta keputusan pembelian sebagai variabel terikat. Teknik pengumpulan data dengan cara menyebaran angket secara online kepada konsumen Nature Republic di Surabaya dengan menggunakan google form. Skala yang digunakan untuk mengukur angket adalah skala likert $1-5$ dengan kategori sangat tidak setuju sampai sangat setuju. Tahap awal uji validitas dan reliabilitas dilakukan kepada 30 responden untuk mengetahui valid dan reliabelnya sebuah intrumen penelitian, kemudian setelah mendapatkan keseluruhan responden sebanyak 110 maka dilakukan kembali uji validitas dan reliabilitas. Teknik analisis data yang digunakan adalah analisis regresi linear berganda dengan menggunakan software SPSS versi 25.

\section{HASIL DAN PEMBAHASAN}

Karakteristik responden dalam penelitian ini dideskripsikan berdasarkan jenis kelamin, usia, pekerjaan, dan juga penghasilan. Sehingga didapatkan hasil karakteristik responden pada penelitian ini adalah responden yang berjenis kelamin perempuan, memiliki usia 15-24 tahun, merupakan pelajar/ mahasiswa, dengan penghasilan $<$ Rp1.500.000.

Keseluruhan jawaban reponden pada variabel kualitas produk memiliki hasil nilai rata-rata yaitu 4,21 dengan kategori sangat setuju. Hal ini menunjukan bahwa kualitas produk dari Nature Republic sangat baik. Kemudian hasil nilai rata-rata jawaban responden tertinggi ada pada indikator kesan dari kualitas, dengan item "Nature Republic mencantumkan informasi yang lengkap tentang produk (komposisi, tanggal kadaluarsa, berat bersih produk)" yaitu 4,50 dengan kategori sangat setuju.

Pada variabel citra merek hasil nilai rata-rata adalah 4,18 dengan kategori setuju. Hasil nilai rata-rata tertinggi ada pada indikator citra produk, pada item pernyataan "Nature Republic menjadi best seller produk berbahan aloevera" yaitu 4,61 dengan kategori sangat setuju.

Kemudian untuk variabel keputusan pembelian hasil nilai rata-rata yaitu 4,15 dengan kategori setuju. Sehingga dapat diketahui bahwa responden pada penelitian ini memilih Nature Republic dalam keputusan pembeliannya. Hasil nilai rata-rata tertinggi ada pada indikator pilihan produk dengan item "Saya memutuskan membeli produk Nature Republic karena manfaat yang diberikan" yaitu 4.45 dengan kategori sangat setuju.

\section{Hasil Uji Asumsi Klasik}

Uji asumsi klasik pada penelitian ini memiliki hasil yaitu pada uji normalitas grafik histogram memiliki kurva yang berbentuk seperti lonceng dan titik tertinggi dari garis melengkung sejajar dengan angka 0. Pada grafik normal p-p plot diketahui bahwa data berada didekat atau mengikuti garis diagonalnya. Kemudian pada uji one sample kolmogorov smirnov yaitu 0,200 >0,05. Sehingga dapat dijelaskan bahwa data berdistribusi normal, dan model regresi pada penelitian ini memenuhi asumsi normalitas. Untuk uji multikolinearitas pada variabel kualitas produk nilai tolerance $0,418>$ 0,1 dan untuk nilai VIF 2,392 < 10. Kemudian untuk variabel citra merek nilai tolerance 0,418>0,1 dan untuk nilai VIF 2,392 < 10. Sehingga tidak ada multikolinearitas antara variabel kualitas produk dan citra merek dalam model regresi. Pada uji heteroskedastisitas nilai signifikansi variabel kualitas produk 0,349>0,05 dan variabel citra merek 0,225 >0,05. Sehingga dapat dimaknai bahwa model regresi pada penelitian ini tidak terjadi heteroskedastisitas.

Tabel 1.

HASIL ANALISIS REGRESI LINEAR BERGANDA

\begin{tabular}{|c|c|c|c|c|c|}
\hline \multirow[b]{2}{*}{ Model } & \multicolumn{2}{|c|}{ Unstandardized Coefficients } & \multicolumn{3}{|l|}{ Standardized Coefficients } \\
\hline & B & Std. Error & Beta & $\mathbf{t}$ & Sig. \\
\hline (Constant) & 6.458 & 2.662 & & 2.426 & .017 \\
\hline Kualitas Produk & .223 & .073 & .321 & 3.035 & .003 \\
\hline Citra Merek & .496 & .122 & .430 & 4.057 & .000 \\
\hline
\end{tabular}

Sumber: Output SPSS versi 25 (2020) 
Annisa Ristanti \& Sri Setyo Iriani. Pengaruh Kualitas Produk dan Citra Merek terhadap Keputusan Pembelian Konsumen Nature Republic di Surabaya

\section{Hasil Analisis Regresi Linear Berganda}

Berdasarkan tabel 1, diperoleh persamaan regresi linear berganda (1) sebagai berikut.

$\mathrm{Y}=6,458+0,223 \mathrm{X} 1+0,496 \mathrm{X} 2$

Dari persamaan (1) tersebut dapat diinterpretasikan bahwa nilai konstanta pada model persamaan regresi linier berganda adalah 6,458 , hal ini memberi arti jika kualitas produk dan citra merek sama dengan nol maka besarnya keputusan pembelian adalah sebesar 6,458. Sehingga nilai positif pada konstanta memiliki makna yaitu meskipun tidak ada variabel kualitas produk dan citra merek keputusan pembelian Nature Republic akan tetap terjadi, karena ada variabel lain yang tidak termasuk dalam penelitian ini sebagai pendukung terjadinya keputusan pembelian.

Nilai koefisien regresi variabel kualitas produk (X1) pada model persamaan regresi linear berganda bernilai positif yaitu 0,223 . Hal ini dapat diartikan jika koefisien bernilai positif maka menunjukan adanya hubungan searah atau pengaruh positif antara kualitas produk dengan keputusan pembelian. Sehingga dapat diketahui, apabila kualitas produk Nature Republic semakin baik maka akan semakin meningkatkan keputusan pembelian.

Nilai koefisien regresi citra merek (X2) pada model persamaan regresi linear berganda bernilai positif yaitu 0,496. Hal ini dapat diartikan jika koefisien bernilai positif maka menunjukan adanya hubungan searah atau pengaruh positif antara citra merek dengan keputusan pembelian. Sehingga dapat diketahui, apabila citra merek Nature Republic semakin baik maka akan semakin meningkatkan keputusan pembelian.

\section{Hasil Analisis Koefisien Determinasi}

Berdasarkan tabel 2, besarnya kontribusi variabel independen kualitas produk (X1) dan citra merek (X2) terhadap variabel dependen keputusan pembelian (Y) berdasarkan nilai adjusted $R$ square adalah 0,489. Sehingga dapat diketahui bahwa kualitas produk (X1) dan citra merek (X2) memiliki pengaruh terhadap keputusan pembelian Nature Republic sebesar 48,9\% (0,489), sedangkan sisanya 51,1\% dipengaruhi oleh variabel lain diluar variabel yang digunakan pada penelitian ini.

Tabel 2.

HASIL ANALISIS KOEFISIEN DETERMINASI

\begin{tabular}{cccc}
\hline $\mathbf{R}$ & R Square & Adjusted R Square & Std. Error of the Estimate \\
\hline .706 & .498 & .489 & 2.961 \\
\hline Sumber: & Output SPSS versi $25(2020)$ &
\end{tabular}

\section{Hasil Uji Hipotesis dengan Uji t}

Hasil uji t pada tabel 3. dapat diketahui bahwa variabel kualitas produk (X1) memiliki hasil nilai $\mathrm{t}$ hitung 3,035 >1,982 dan memiliki nilai signifikansi $0,003<0,05$. Sehingga ada pengaruh signifikan antara variabel kualitas produk (X1) terhadap keputusan pembelian (Y).

Kemudian untuk variabel citra merek (X2) memiliki hasil nilai t hitung 4,057 > 1,982 dan memiliki nilai signifikansi $0,000<0,05$. Maka ada pengaruh signifikan antara variabel citra merek (X2) terhadap keputusan pembelian (Y).

\section{Pengaruh Kualitas Produk terhadap Keputusan Pembelian}

Hasil pada penelitian ini menunjukan bahwa kualitas produk (X1) berpengaruh signifikan terhadap keputusan pembelian (Y). Artinya konsumen Nature Republic di Surabaya mempertimbangkan kualitas produk pada saat memutuskan untuk membeli Nature Republic. Dengan memiliki hubungan yang searah atau memiliki pengaruh yang positif, maka semakin baik kualitas produk yang dimiliki oleh Nature Republic membuat keputusan konsumen untuk membeli Nature Republic semakin tinggi. 
Penelitian ini mendukung penelitian yang dilakukan Erdalina \& Evanita (2015) yang memiliki variabel serupa mengenai perawatan tubuh, bahwa banyak pertimbangan yang dilakukan konsumen mempertimbankan kualitas produk sebelum memutuskan membeli. Alfred (2013) mengemukakan bahwa kualitas digunakan untuk memuaskan konsumen. Hasil penelitian ini juga mendukung penelitian dari Rahman \& Sitio (2019); Ananingsih et al.; (2018); Saputra et al. (2017) bahwa kualitas produk berpengaruh signifikan terhadap keputusan pembelian. Tetapi penelitian ini tidak sejalan dengan penelitian yang dilakukan oleh Pardede \& Haryadi (2017) keputusan pembelian konsumen tidak dipengaruh secara positif dan signifikan oleh kualitas produk.

Mayoritas responden pada penelitian ini sangat setuju bahwa Nature Republic memiliki kualitas produk yang sangat baik. Hal yang paling dipertimbangkan responden pada variabel kualitas produk berasal dari kesan dari kualitas, yang mana responden menyatakan bahwa Nature Republic telah mencantumkan informasi yang lengkap tentang produk (komposisi, tanggal kadaluarsa, berat bersih produk). Hal ini menunjukan bahwa kualitas produk Nature Republic yang baik menurut responden adalah dengan mencantumkan informasi yang lengkap pada setiap produknya, karena dengan adanya informasi komposisi, tanggal kadaluarsa, berat bersih yang tercantum pada produk membuat konsumen dapat mengetahui tentang formulasi bahan baku apa saja yang ada pada produk Nature Republic yang mereka beli, seberapa lama mereka dapat menggunakan produk Nature Republic tersebut, dan sampai kapan produk yang mereka beli aman untuk digunakan.

Berdasarkan karakteristik responden, penelitian ini didominasi oleh responden perempuan karena mereka lebih peduli akan penampilan diri sehingga membutuhkan kosmetik Nature Republic untuk merawat dan mempercantik diri. Dengan memiliki usia 15-24 tahun, mayoritas pelajar/ mahasiwa yang memiliki penghasilan < Rp1.500.000. Responden memutuskan membeli Nature Republic karena mereka sedang dihadapkan dengan banyak masalah kulit yang diakibatkan dari beragam aktivitas mereka di dalam maupun di luar ruangan, seperti terkena AC maupun sinar matahari langsung. Oleh karena itu mereka membutuhkan kosmetik yang dapat mengatasi masalah kulit yang sedang dihadapi. Maka pada saaat mereka memutuskan untuk membeli mereka akan melihat informasi yang tertera pada produk yang dimiliki Nature Republic sebagai acuan atau arahan mereka untuk lebih paham tentang produk yang akan dibeli, sehingga dapat menemukan produk yang sesuai dengan yang mereka butuhkan, selain itu informasi yang lengkap juga berguna untuk meningkatkan kepercayaan terhadap produk dan meminimalisir kesalahan saat membeli produk Nature Republic. Dengan pengahasilan yang <Rp1.500.000 mereka masih bisa menjangkau untuk membeli produk kosmetik yang berkualitas seperti Nature Republic, harga termurah produk Nature Republic yaitu produk sheet mask beraneka varian mulai dari buah-buahan, madu, hingga bambu hanya dengan mengeluarkan uang sebesar Rp18.000 responden remaja/mahasiswa sudah dapat merawat diri.

\section{Pengaruh Citra Merek terhadap Keputusan Pembelian}

Hasil penelitian ini menunjukan bahwa variabel citra merek (X2) berpengaruh signifikan terhadap keputusan pembelian (Y). artinya konsumen Nature Republic di Surabaya mempertimbangkan citra merek pada saat memutuskan membeli Nature Republic. Dengan memiliki hubungan yang searah atau memiliki pengaruh yang positif, maka semakin baik citra merek yang dimiliki oleh Nature Republic membuat keputusan konsumen untuk membeli Nature Republlic semakin tinggi.

Penelitian ini sejalan dengan hasil penelitian dari Lin (2007) bahwa Konsumen merasa puas membeli produk dari merek - merek terkenal, karena konsumen memiliki keyakinan bahwa merek terkenal lebih bisa dipercaya. Supriyadi et al. (2016) konsumen yang memiliki citra positif terhadap suatu merek tertentu, akan lebih memungkinkan konsumen tersebut untuk melakukan pembelian. Kemudian menurut Fianto et al. (2014) bahwa semakin baik citra merek maka semakin cepat konsumen melakukan keputusan pembelian. Selanjutnya didukung juga oleh penelitian dari Yulianingsih (2018) dan Mutiara \& Madiawati (2019) bahwa citra merek berpengaruh signifikan terhadap keputusan pembelian. Namun meskipun memiliki objek yang serupa yaitu kosmetik, penelitian ini tidak sejalan dengan hasil penelitian Putri et al. (2018); dan Sone (2019) yang diketahui bahwa variabel citra merek tidak berpengaruh secara signifikan terhadap keputusan pembelian. 
Annisa Ristanti \& Sri Setyo Iriani. Pengaruh Kualitas Produk dan Citra Merek terhadap Keputusan Pembelian Konsumen Nature Republic di Surabaya

Responden pada penelitian ini setuju bahwa Nature Republic memiliki citra yang positif. Pertimbangan responden pada variabel citra merek berasal dari citra produknya, yang mana Nature Republic merupakan merek kosmetik penjualan terbaik untuk produk yang berasal atau berbahan baku aloevera. Hal ini menunjukan bahwa citra positif yang dimiliki Nature Republic berasal dari citra produk aloevera yang menjadi unggulan dari Nature Republic, meskipun banyak merek lain yang mengeluarkan produk serupa tetapi Nature Republic tetap menjadi yang teratas untuk penjualan produk aloevera. Sehingga dalam memutuskan membeli Nature Republic responden melihat citra positif produk aloevera untuk meyakinkan diri bahwa produk Nature Republic lainnya juga memiliki citra yang baik.

Berdasarkan karakteristik responden, penelitian ini didominasi oleh responden perempuan dengan rentan usia 15-24 tahun, merupakan pelajar/ mahasiswa, dengan penghasilan $<\mathrm{Rp} 1.500 .000$. Sehingga dapat dimaknai bahwa mayoritas responden yang merupakan usia muda atau remaja mempertimbangkan membeli produk dengan melihat tren yang terjadi saat ini yaitu korean wave, termasuk k-beauty didalamnya. Responden memilih Nature Republic karena citra positif yang didapat dari citra produk aloeveranya. Alasan aloevera gel Nature Republic menjadi best seller dan mengalahkan produk serupa dari para pesaingnya karena aloevera gel Nature Republic memiliki beragam manfaat, seperti menyamarkan bekas jerawat, menghilangkan kantung mata dan mata panda, untuk sleeping mask, sebagai primer sebelum makeup, sebagai masker wajah, melembutkan bagian kulit yang kasar, menenangkan kulit setelah terbakar matahari, pengganti body lotion, melembabkan bibir, dan sebagai perawatan rambut rusak. Penggunaan bahan alami pada setiap produknya seperti aloevera membuat Nature Republic aman digunakan untuk responden yang masih remaja tanpa harus takut akan timbul efek samping setelah penggunaan produk. Selain itu responden lebih memilih Nature Republic karena produk aloevera merupakan pionir atau pelopor maraknya aloevera gel di indonesia, setelah populernya aloevera gel Nature Republic muncul banyak produk berbahan aloevera yang dibuat oleh para pesaing. Sebagai pelopor aloevera gel membuat Nature Republic menjadi merek Korea yang paling dicari oleh para responden yang mayoritas adalah perempuan. Harga dari aloevera gel ini juga termasuk murah dan terjangkau untuk kantong pelajar/mahasiswa yang memiliki penghasilan <Rp1.500.000. Produk aloevera gel Nature Republic juga memiliki ukuran yang lumayan besar sehingga awet meskipun digunakan setiap hari.

\section{KESIMPULAN}

Penelitian ini membuktikan pengaruh yang signifikan antara kualitas produk tehadap keputusan pembelian Nature Republic di Surabaya, kemudian ada pengaruh yang signifikan antara citra merek terhadap keputusan pembelian Nature Republic di Surabaya, dan variabel yang memiliki pengaruh lebih besar terhadap keputusan pembelian adalah variabel citra merek.

Keterbatasan yang dihadapi yaitu sampel yang digunakan terbatas 110 responden dan hanya mengetahui keputusan pembelian konsumen Nature Republic di Surabaya, hanya menggunakan 2 variabel bebas, serta tidak menggunakan variabel mediasi ataupun moderasi. Penelitian selanjutnya dapat melibatkan variabel lain seperti variabel pengetahuan produk yang merupakan pertimbangan penting dalam proses evaluasi produk sebelum melakukan keputusan pembelian.

Implikasi manajerial yang dapat diterapkan yaitu dengan kualitas produk yang baik dari Nature Republic akan membuat permintaan terhadap produk meningkat karena konsumen percaya akan kualitas yang dimiliki Nature Republic. Perusahaan harus terus berupaya mempertahankan dan meningkatkan kualitas dengan memperhatikan faktor lain selain kesan dari kualitas, kemudian Nature Republic perlu untuk mempertahankan citra positif tentang produknya, karena citra positif dari produk Nature Republic dapat dijadikan sebagai keunggulan untuk menghadapi para pesaing serta dapat memberikan keuntungan bagi perusahaan pada saat akan merilis produk baru ataupun saat ingin melakukan ekspansi. 


\section{DAFTAR PUSTAKA}

Alfred, O. (2013). Influences of Price And Quality On Consumer Purchase Of Mobile Phone In The Kumasi Metropolis In Ghana A Comparative Study. European Journal of Business and Management, 5(1), 179-199.

Ananingsih, T., Hasiholan, L. B., \& Wahyono, E. H. (2018). Pengaruh Kualitas Produk, Promosi, Harga dan Saluran Distribusi Terhadap Keputusan Pembelian Produk Johnson and Johnson Indonesia. Pengaruh Kualitas Produk, Promosi, Harga Dan Saluran Distribusi Terhadap Keputusan Pembelian Produk Johnson and Johnson Indonesia, 1-10.

Andrianto, H. N., \& Idris, I. (2013). MPV Merek Toyota Kijang Inova Di Semarang. Dipenogoro Journal Of Management, 2(3), 1-10.

Anggitasari, A. M. (2016). Pengaruh EWOM Terhadap Brand Image dan Brand Trust Serta Dampaknya pada Minat Beli Produk Smartphone (Studi Pada Mayarakat di Yogyakarta). Universitas Negeri Yogyakarta.

Bella, A. (2018). Di Balik Kesuksesan Merek Kecantikan Korea. https://marketeers.com/di-balikkesuksesan-merek-kecantikan-korea/

Brata, B. H., Husani, S., \& Ali, H. (2017). The Influence of Quality Products, Price, Promotion, and Location to Product Purchase Decision on Nitchi At PT. Jaya Swarasa Agung in Central Jakarta. Saudi Journal of Business and Management Studies, 2(4B), 433-445. https://doi.org/10.21276/sjbms

Engel, J. F., Blackwell, R. D., \& Miniard, P. W. (1995). Perilaku Konsumen (Edisi 6 Ji). Jakarta : Binarupa Aksara.

Erdalina, W., \& Evanita, S. (2015). Pengaruh kualitas produk, harga dan iklan televisi terhadap keputusan pembelian produk kosmetik merek citra. Jurnal Riset Manajemen Bisnis Dan Publik, $3(1), 1-18$.

Fianto, A. Y. A., Hadiwidjojo, D., Aisjah, S., \& Solimun, S. (2014). The Influence of Brand Image on Purchase Behaviour Through Brand Trust. Business Management and Strategy, 5(2), 58. https://doi.org/10.5296/bms.v5i2.6003

Habibah, U., \& Sumiati. (2016). Pengaruh Kualitas Produk Dan Harga Terhadap Keputusan Pembelian Produk Kosmetik Wardah Di Kota Bangkalan Madura. Jurnal Ekonomi, Bisnis \& Entrepreneurship, 1(1), 31-48.

Hardum, S. E. (2019). Awas, Nature Republic Palsu dan Ilegal Serbu Pasar. https://www.beritasatu.com/bisnis/534493/awas-nature-republic-palsu-dan-ilegal-serbu-pasar

Huda, L. (2020). Perubahan Gaya Hidup Dorong Industri Kosmetik. https://koran.tempo.co/read/ekonomi-dan-bisnis/449594/perubahan-gaya-hidup-dorongindustri-kosmetik?

Indrawati, D. (2015). Pengaruh Citra Merek Dan Gaya Hidup Hedonis Terhadap Keputusan Pembelian Jilbab "Zoya." Jurnal Riset Ekonomi Dan Manajemen, 15(2), 302. https://doi.org/10.17970/jrem.15.150207.id

Junianti, D. (2003). Studi Pengaruh Atribut Produk Terhadap Keputusan Pembelian Lensa Kontak Pada Konsumen Perusahaan Optik di Yogyakarta. Universitas Islam Indonesia. 
Annisa Ristanti \& Sri Setyo Iriani. Pengaruh Kualitas Produk dan Citra Merek terhadap Keputusan Pembelian Konsumen Nature Republic di Surabaya

Kotler dan Kevin Lane Keller. (2009). Manajemen Pemasaran. Jakarta: Gelora Aksara Pratama.

Kotler, P., \& Amstrong, G. (2014). Principles of Marketing (Edisi 15 J). Jakarta : Erlangga.

Lengkong, S. L., Sondakh, M., \& Londa, J. . (2017). Strategi Public Relations Dalam Pemulihan Citra Perusahaan (Studi Kasus Rumah Makan Kawan Baru Megamas Manado). Acta Diurna, VI(1), 1-46. https://ejournal.unsrat.ac.id/index.php/actadiurnakomunikasi/article/view/15493/15034

Li, X. G., Wang, X., \& Cai, Y. J. (2011). Corporate-, product-, and user-image dimensions and purchase intentions: The mediating role of cognitive and affective attitudes. Journal of Computers, 6(9), 1875-1879. https://doi.org/10.4304/jcp.6.9.1875-1879

Lin, N.-H. (2007). The Effect of Brand Image and Product Knowledge on Purchase Intention. Journal of International Management Studies, January, 121-132.

Lukihardianti, A., \& Murdaningsih, D. (2018). Korean Beauty akan Jadi Tren Kecantikan di Indonesia. https://www.republika.co.id/berita/gaya-hidup/trend/18/02/23/p4ls53368-koreanbeauty-akan-jadi-tren-kecantikan-di-indonesia

Mutiara, \& Madiawati, P. N. (2019). Pengaruh Electronic Word dan Citra Merek Terhadap Keputusan Pembelian Nature Republic Aloe Vera 92\% Soothing Gel. E-Proceeding of Management, 6(1), 1099-1106.

Naturerepublic.id. (2018). Real Or https://www.instagram.com/stories/highlights/17920982788229068/, diakses pada 1 Januari 2020.

Naturerepublic.id. (2019). Nature Republic Product. https://naturerepublic.id/shop/

Pardede, R., \& Haryadi, T. Y. (2017). Pengaruh Persepsi Harga Dan Kualitas Produk Terhadap Keputusan Pembelian Konsumen Yang Dimediasi Kepuasan Konsumen. Journal of Business \& Applied Management, 10(1). https://doi.org/10.30813/jbam.v10i1.870

Pratama, A. P. (2018). Suka K-Pop dan K-Drama? 6 Brand Kosmetik Korea Ini Patut Dilirik! https://kpopchart.net/2018/10/suka-k-pop-dan-k-drama-6-brand-kosmetik-korea-ini-patutdilirik.html

Puspitasari, C., Sulistyarini, R., \& Eta Widyanti, Y. (2011). IMPLEMENTASI PASAL 8 AYAT 1 HURUF (E) UNDANG-UNDANG REPUBLIK INDONESIA NOMOR 8 TAHUN 1999 TENTANG PERLINDUNGAN KONSUMEN (Studi Pengawasan Kosmetik Palsu oleh BBPOM Surabaya). 1-18.

Putri, T. (2019). Masih Jadi Tren, Ini 3 Alasan Kosmetik Asal Korea Begitu Digemari. https://lifestyle.okezone.com/read/2019/12/06/611/2138601/masih-jadi-tren-ini-3-alasankosmetik-asal-korea-begitu-digemari

Putri, T. A., Marwan, \& Rahmidani, R. (2018). Pengaruh Brand Image dan Perceived Quality Terhadap Keputusan Pembelian Produk LA Tulipe di kota Padang. 1, 734-743.

Rahman, H. A., \& Sitio, A. (2019). the Effect of Promotion and Product Quality Through Purchase Decision on the Customer Satisfaction of Bohemian Project . Id Products. International Journal of Engineering Technologies and Management Research, 6(January). https://doi.org/10.5281/zenodo.2555331

Rommy, A. S. N., Moh, N. B. H. H., \& Nur, A. R. Y. N. (2018). Effect Of Brand Image And Price 
Perception On Purchase Decision. Journal of Business and Management, 20(8), 76-81. https://doi.org/10.9790/487X-2008027681

Saputra, S., Hidayat, K., \& Sunarti, S. (2017). PENGARUH KUALITAS PRODUK TERHADAP KEPUTUSAN PEMBELIAN DAN DAMPAKNYA TERHADAP KEPUASAN KONSUMEN PENGGUNA IPHONE (Survei pada Mahasiswa Fakultas Ilmu Administrasi Universitas Brawijaya Malang). Jurnal Administrasi Bisnis S1 Universitas Brawijaya, 50(6), 85-95.

Setiadi, N. (2003). Perilaku Konsumen: Konsep dan Implikasi untuk Strategi dan Penelitian Pemasaran. Kencana.

Shimp, A. T. (2014). Komunikasi Pemasaran Terpadu dalam Periklanan dan Promosi (Edisi : 8). Salemba Empat.

Sone, H. T. P. (2019). The Effect of Brand Image, Product Quality and Sales Promotion to Thai Consumers Decisions to Purchase Korean Brand Cosmetics in Bangkok District. Bangkok University.

Su, Y., \& Lai, C. (2017). Electronic Word-of-Mouth , Experiential Marketing , Brand Image , Brand Loyalty, and Purchase Intention: a. International Journal of Information Technology and Business Management, 60(1), 1-18.

Sumarwan, U. (2015). Perilaku Konsumen: Teori dan penerapannya dalam Pemasaran (Edisi 2). Bogor: Ghalia Indonesia.

Supriyadi, Fristin, Y., \& Indra, G. K. . (2016). Pengaruh Kualitas Produk dan Brand Image Terhadap Keputusan Pembelian (Studi pada Mahasiswa Pengguna Produk Sepatu Merek Converse di Fisip Universitas Merdeka). Jurnal Bisnis Dan Manajemen, Vol. 3 No.(1), 1.

Sutisna. (2001). Perilaku Konsumen dan Komunikasi Pemasaran. Bandung: PT Remaja Rosdakarya.

Swastha, B. dan I. (2008). Menejemen Pemasaran Modern. Yogyakarta : LIBERTY.

Taqwa, Y. (2020). Kosmetik Impor Menggerogoti Pasar dalam Negeri. http://pelakubisnis.com/2020/02/kosmetik-impor-menggerogoti-pasar-dalam-negeri/

Yulianingsih. (2018). Hubungan Antara Kualitas Produk dan Citra Merek Dengan Keputusan Pembelian pada PT. Hyundai Mobil Indonesia Cabang Serpong-Tangerang. Jurnal Visionida, 4, 23-37.

ZAP. (2020). ZAP Beauty Index 2020. https://zapclinic.com/zapbeautyindex/2020 